Article

\title{
Sustainability Assessment in Automotive and Electronics Supply Chains-A Set of Indicators Defined in a Multi-Stakeholder Approach
}

\author{
Josef-Peter Schöggl *, Morgane M. C. Fritz and Rupert J. Baumgartner \\ Institute of Systems Sciences, Innovation and Sustainability Research, University of Graz, Merangasse 18/I, \\ 8010 Graz, Austria; morgane.fritz@uni-graz.at (M.M.C.F.); rupert.baumgartner@uni-graz.at (R.J.B.) \\ * Correspondence: josef.schoeggl@uni-graz.at \\ Academic Editor: Ilkyeong Moon \\ Received: 26 July 2016; Accepted: 8 November 2016; Published: 17 November 2016
}

\begin{abstract}
In automotive and electronics supply chains, sustainability assessment is gaining increasing importance. More stringent regulations and growing customer pressure are driving the change towards more environmentally, socially and economically responsible supply chains. Since this implies a rising use of resources for data collection, monitoring, exchange and assessment, the objective of this paper is to facilitate supply chain sustainability assessment. The present paper first provides a tailored set of 69 supply chain sustainability indicators for the European automotive and electronics industries. These were derived on the basis of a systematic literature review, together with 13 semi-structured interviews and five focus group workshops, all of which involved sustainability and industry experts. Second, the paper provides a case example of software-based supply chain sustainability data exchange. The extent to which sustainability information is currently exchanged in the two industries is also analyzed. The set of indicators is scientifically relevant since it considers all three dimensions of sustainability and is intended to allow for supply chain-wide sustainability assessment in two specific industries. It is also of high practical relevance since it was developed with and validated by industry experts, and also since it considers industrial and technical requirements for supply chain sustainability assessment in order to increase the efficiency of the work processes.
\end{abstract}

Keywords: supply chain management; green supply chain management; sustainability indicators; sustainability metrics; automotive industry; electronics industry

\section{Introduction}

The growing complexity of global supply chains, the shift in competition from the inter-firm to the inter-supply chain level, and the fact that companies continually need to deal with cost-reduction and stakeholder pressures, all serve to ensure that sustainable supply chain management (SSCM) is becoming of ever greater importance [1,2].

The present paper focuses on the automotive and electronics industries. These two areas are at the forefront of developments when it comes to the adoption of SSCM practices [3,4]. Both industries are facing increased public pressure, see, for example, the public outcry at the inhuman working conditions at Foxconn in 2011, or the emissions level scandal in the more recent case of Volkswagen in 2015. Speaking more generally, we often find that focal companies voluntarily engage on sustainability issues, also through common codes of conduct such as the one by the Electronic Industry Citizenship Coalition (EICC), which focuses on aspects such as labor, health and safety, environment and ethics [5]. Besides the various voluntary initiatives, regulatory frameworks also serve to drive companies towards engaging in an exchange of sustainability information in order to avoid the risks of non-compliance [6]. For instance, both of the above mentioned industries are already bound to 
comply with sustainability-related regulations in the European Union such as REACH or RoHS, which affect their data management practices along the supply chain. There is also the End of Life Vehicle (ELV) Directive, which focuses on increasing the recyclability of passenger vehicles [7-9]. Another example is the U.S. Dodd Frank Act's Section 1502 on conflict minerals, which affects all members of American companies' supply chains worldwide where tin, tungsten, gold and tantalum are used as raw materials [10]. For such compliance-related topics, companies already assess and exchange sustainability-related information along the supply chain. It is normal for focal companies to require that suppliers provide them with sustainability information according to a specific template [11]. However, since suppliers may serve several different focal companies, this approach implies that for each focal company, suppliers have to provide a variety of different datasets. This relatively heavy workload then often leads to error or lack of data reliability [12].

In contrast, in the majority of sustainability topics, sustainability assessment mainly takes place with respect to original equipment manufacturers (OEMs) and their direct suppliers [4]. Regarding such bilateral assessments, a variety of approaches have already been outlined in the relevant literature [13-15]. Concerning the assessment of non-regulated sustainability topics throughout supply chains, a considerable need for research still exists [16]. There is especially a need for clearly defined metrics using standardized terminology in order to cope with the particular circumstances of different supply chains [17].

With this in mind, the objective of this paper is to analyze the literature on supply chain sustainability assessment. The focus here is on the derivation of specific sustainability indicators for the automotive and electronics industries and is based on the framework for supply chain-wide sustainability assessment suggested by Schöggl et al. [12] and on a set of supply chain sustainability aspects proposed by Fritz et al. [18]. This paper can thus be seen as an example of framework application with regard to a specific set of supply chain sustainability indicators for the European automotive and electronics industries. The two industries selected here were chosen because they were deemed to be representative of a wide variety of sustainability issues [19]. Both industries encompass global and interlinked supply chains and are already exposed to legal and public pressure and associated environmental and social issues [18].

The remainder of this paper is structured as follows. The following two sections describe the research background and methods of the study. Section 4 provides the interim results of the indicator development. The set of supply chain sustainability indicators for the European automotive and electronics industries is outlined in Section 5. Section 6 illustrates how the indicators can be integrated into a software-based sustainability data exchange hub and the extent to which sustainability information is currently being exchanged in the two target industries. Finally, Section 7 discusses the results, describes the relevant constraints, and provides suggestions for further research.

\section{Background}

\subsection{ASSC Framework}

Supply chain sustainability metrics, assessment and performance evaluation are clearly gaining in importance. There is a growing number of publications providing suggestions for suitable frameworks and methods $[17,20,21]$. However, the majority of these frameworks and assessment methods focus on the bilateral assessments of direct suppliers [12].

Since a supply chain-wide perspective is essential for improving the sustainability performance of organizations and products, Schöggl et al. [12] suggest making use of the Assessment of Supply Chain Sustainability (ASSC) framework, as illustrated in Figure 1. This framework first provides the foundation for assessing the social, environmental and governance aspects of sustainability with the aid of qualitative and quantitative indicators (1. Information collection in Figure 1). Second, it encompasses different methods for processing (2. Information processing) and aggregating (3. Indicator aggregation) suppliers' sustainability information into supply chain sustainability key performance indicators (KPIs) 
(see Schöggl et al. [12] for more details). The ASSC framework, which was developed with the help of industrial experts from the European automotive and electronics industries, does not, however, encompass a definite set of supply chain indicators, since these indicators cannot be defined globally. As Clift [22] or Courville [23] state, such supply chain sustainability indicators must be developed on a case by case basis, meaning that for specific industries or even for specific organizations, specific indicators have to be used. Therefore, in this paper a set of qualitative and quantitative supply chain sustainability indicators is developed specifically for the European automotive and electronics industries. These indicators were developed after the ASSC framework was conceptualized in order to illustrate how indicators can be integrated into the framework while taking account of industrial requirements, as outlined in Section 4.3.1.

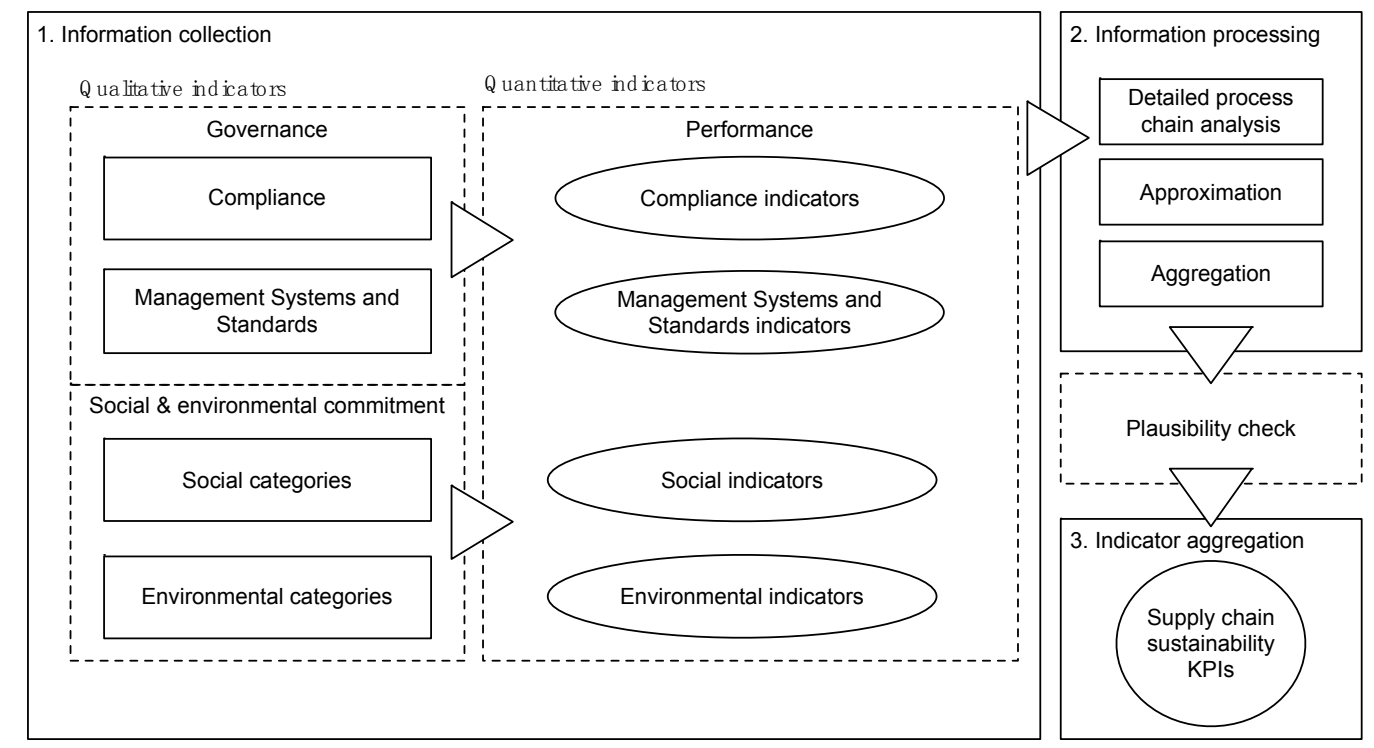

Figure 1. Assessment of Supply Chain Sustainability (ASSC) framework [12] (Permission from Elsevier: Schöggl J.-P.; Fritz M.M.C.; Baumgartner R.J. Toward supply chain-wide sustainability assessment: A conceptual framework and an aggregation method to assess supply chain performance. J. Clean. Prod. 2016, 131, 822-835).

\subsection{Sustainability Indicators}

Since in the standard literature, the term "sustainability indicator" is often used interchangeably with other terms such as "sustainability metric", "sustainability parameter" or "sustainability measure", it will be helpful to define how it is used here. Sustainability indicators are defined here as "information used to measure and motivate progress towards sustainable goals". More specifically, sustainability indicators can be considered as variables that are "operational representations of attributes of a system" [24]. Hence, indicators are a step beyond primary data, since they allow for the analysis and comparison of data in different contexts, and for varying purposes. This implies that indicators need to be carefully selected in order to ensure that what is measured is in fact applicable for the specific purpose at hand. Since it is a particular aim in this paper to also provide indicators on social sustainability issues in supply chains, which are not always easily and meaningfully quantifiable, we also draw on the definition employed by Ahi and Searcy [17]. They define "sustainability indicators" as quantitative and qualitative variables of measurement, i.e., they are not viewed as being mere "sustainability metrics", or purely quantitative variables of measurement.

\subsection{Sustainable Supply Chain Management}

This paper is set in the context of sustainable supply chain management (SSCM). The latter refers to the alignment of supply chain (SC) practices with the concept of sustainable development, as defined by the Brundtland report [25] and serves to operationalize the triple bottom line (TBL), i.e., the people, 
planet, profit paradigm [26]. SSCM can be seen as an extension of corporate sustainability activities to "... all the organizations involved in all the upstream and downstream flows of products, services, finances, and information from the ultimate supplier to the ultimate customer" [27]. Building on this understanding, Ahi and Searcy [28] recently defined SSCM as "... the creation of coordinated supply chains through the voluntary integration of economic, environmental, and social considerations with key inter-organizational business systems designed to efficiently and effectively manage the material, information, and capital flows associated with the procurement, production, and distribution of products or services in order to meet stakeholder requirements and improve the profitability, competitiveness, and resilience of the organization over the shortand long-term". This guides the research provided in this paper and helps to define the boundaries of supply chain-wide assessment.

\section{Methods}

In developing the set of supply chain sustainability indicators, the 5-step research process illustrated in Figure 2 was conducted.

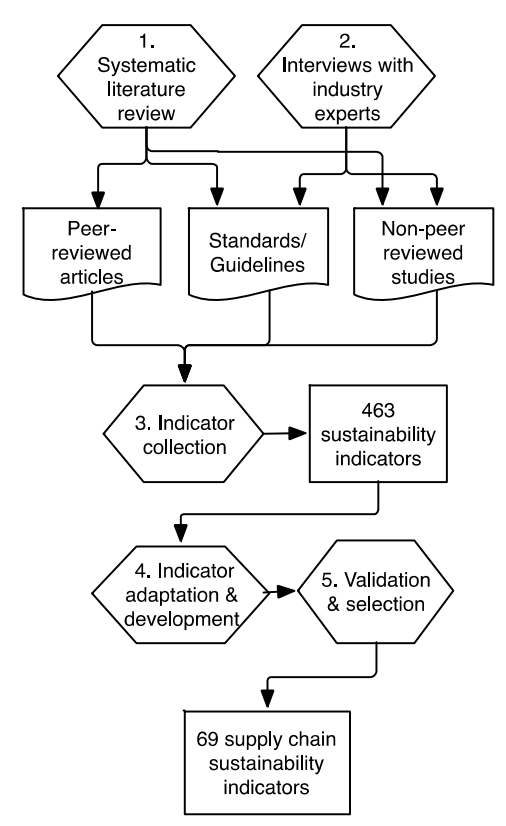

Figure 2. Overview of the 5-step research process for developing the set of supply chain sustainability indicators.

\subsection{Systematic Literature Review}

First, in order to obtain a basis for the development of the indicator set, a systematic literature review was conducted [29]. The boundaries of the analysis were specified by using the following keywords: "sustainable supply chain management" or "green supply chain management" and "indicator". The scope was kept relatively narrow since the aim of this review was specifically to identify and compile supply chain sustainability indicators which had already been developed. Reviews with a broader focus are, for instance, provided by Ahi and Searcy [17] or Hassini et al. [16]. The literature review was conducted on peer-reviewed articles extracted from the online databases "Scopus" and "Web of Knowledge". The time period included all publications up to November 2014. In total, 26 scientific, peer-reviewed papers (research articles and reviews) written in English were included in the review. A search of keywords was made in article title, abstract and authors' keywords. No restriction was made concerning the field of research. Furthermore, in order to extend the initial literature foundation and thus help indicator development, a snowball sampling approach as suggested by Fink [29] was also applied. Thus, the focus was extended to sustainability indicators with a view to application in a broader business context by starting from the initial set of 26 peer-reviewed articles. 


\subsection{Interviews}

Second, in order to integrate a practical perspective when developing the set of indicators, thirteen semi-structured qualitative interviews were also conducted. These interviews aimed at gaining an understanding of the current state of SSCM, of assessment and data exchange in the target industries, and helped identify relevant sources for indicator development. The group of interviewees consisted of three companies, five interest groups and five NGOs in the electronics and automotive industries based in Europe. The 13 interview partners derived from an initial sample of 25 organizations contacted, and were selected based on their presence and importance in the target industries and on their sustainability-related activities. The interviews were transcribed and analyzed via qualitative content analysis using the software MaxQDA, in accordance with the method used by Mayring and Gläser-Zikuda [30]. The identification of additional sources from the literature and via interviews was terminated once saturation point was reached, i.e., the point at which additional research would not provide new information [31].

\subsection{Content Analysis}

Third, sustainability indicators found in the identified sources by means of a content analysis were documented and grouped according to a list of 36 aspects of supply chain sustainability for the European automotive and electronics industries. This list was adopted from Fritz et al. [18], and is based on an analysis of the particular requirements of the target industries. This research step (described in more detail in Section 4.2 below) was conducted by the authors and resulted in a list of 463 sustainability indicators.

\subsection{Focus Groups}

Fourth, the set of supply chain sustainability indicators was developed in an iterative process and entailed constant consultation with industry experts. Based on the list of 463 indicators, either existing indicators were selected and adapted, or new indicators were developed. The development of indicators involved five focus group workshops with industry experts from the European automotive and electronics industries, consultants and researchers in the field of sustainability and supply chain management, and followed the method suggested by Henseling et al. [32] (see Schöggl et al. [12] for more details on the methodological foundation of the focus group workshops). The focus group workshops were used to condense the number of indicators and to assess which types of indicators should be provided (e.g., qualitative/quantitative, total/relative, product/organizational level, etc.). Furthermore, the focus groups served to analyze the assessment boundaries for different types of indicators and to validate them in the fifth step. In total, 69 indicators were thus developed and adapted accordingly. In the final stage of the project, specific focus was placed on the feasibility of aggregating supply chain data in terms of the following three indicators: "Gender awareness", "Energy consumption" and "Hazardous substances" (see Section 6.1).

\subsection{Maturity Analysis}

Finally, for each of the 69 indicators the maturity of supply chain data exchange was estimated. This estimation, which is provided in Section 6.2, is based on the review of standards and templates for data collection and exchange (see Table S2 in the Supplementary Material), as identified in the course of the literature review, the interviews and focus group workshops. These standards and templates were then analyzed, categorized and matched with the 69 indicators.

\section{Development of the Supply Chain Sustainability Indicator Set}

In this section the interim results of the five-step research process depicted above are presented. The results of the systematic literature (Step 1) and the interviews with industry experts (Step 2), conducted to identify possible indicator sources, are summarized in Section 4.1. Step 3, the collection of indicators is explained in more detail in Section 4.2. The adaptation and development of indicators (Step 4) and their validation via the focus group workshops (Step 5) are provided in Section 4.3. 


\subsection{Identification of Sources from Literature and Industry}

The literature on sustainability indicators in general is extensive and ever-growing [33]. Authors such as Singh et al. [34] or Böhringer and Jochem [35] provide comprehensive reviews of the different types of indicators for monitoring and steering activities for sustainable development. The literature on specific supply chain sustainability indicators is, however, still limited [17]. Although there are already many frameworks (e.g., $[16,36,37])$ and approaches for either integrating sustainability issues into supplier selection (e.g., [38-40]) or assessing the potential environmental impacts of a product via traditional or modified life cycle assessment (LCA) approaches (e.g., [41,42]), the literature on sustainability indicators for use in supply chain-wide assessment is relatively rare. However, frameworks like those of Gunasekaran [43], Hassini et al. [16] or Ahi and Searcy [17] do provide a basis for further development of a supply chain-wide approach: see for example, Hassini et al. [16] and Shokravi and Kurnia [33].

\subsubsection{Sustainability Assessment in the Automotive and Electronics Industries}

Some studies particularly focus on sustainability assessment in supply chains of the automotive and electronics industries. Koplin et al. [11] provide a suitable framework in a case study on the incorporation of sustainability into the supply management of Volkswagen AG. Kannegiesser et al. [44] apply their sustainability optimization framework to the European automotive industry. They conclude in their study, which is based on numerical experiments, that the European automotive industry has great potential for sustainability improvements, particularly regarding the balance of costs and emissions. Olugu et al. [45] propose a set of 16 key performance measures and 72 metrics and test their relative importance by means of a survey of academics and practitioners. Diabat et al. [3] apply a fuzzy multiple criteria decision-making method for assessing the importance of GSCM practices and performance in an automotive company. Finally, Wittstruck and Teuteberg [4] analyze critical success factors for SSCM in the automotive industry. One success factor they identify, which is of particular relevance for this paper, is that constant exchange of information is beneficial for all supply chain partners. They furthermore highlight that the provision of relevant key figures supports the monitoring and control of sustainable activities throughout the supply chain [4].

This need for key figures, provided via the application of an indicator set, is also supported by the most recent systematic literature review on sustainability metrics in GSCM and SSCM by Ahi and Searcy [17].

\subsubsection{Results of the Systematic Literature Review}

The systematic literature review revealed that the first journal article focusing on supply chain sustainability assessment, according to the keyword-based search, was published in 2006. Since then, only 26 peer-reviewed articles have been published which specifically focus on SSCM or GSCM and indicators. As the analysis of these publications furthermore revealed, only Genovese et al. [46], Wang et al. [47] and Hanson and Holt [48] provide sustainability indicators matching the definition provided in Section 2.2. The majority of the remaining sources $(55 \%)$ provide no indicators. Twenty-three percent of the publications remained on the level of specific sustainability issues (i.e., discussing GHG emissions, energy or waste topics), without providing measurable indicators and $14 \%$ discuss more general categories of sustainability (human rights, environmental pollution, etc.). This thus validated the extension of the research focus via snowball sampling, by means of which an additional six indicator sources were identified.

Among these additional sources, Veleva and Ellenbecker [24] provide a comprehensive and structured list of 22 core indicators, plus a selection of potential supplementary environmental and social indicators for sustainable production. Salvado et al. [49] furthermore propose a set of business sustainability indicators that can also be applied for assessing the performance of a company's supply chain partners. Ahi and Searcy [17] extract sustainability metrics, i.e., quantitative indicators, from the literature and categorize them according to 50 themes such as "management systems", "quality", "energy use" or "ISO 14001 certification". Chen and Xiu [50] use a set of 24 sustainability indicators 
for green supply chain management performance evaluation in an analytic network process (ANP) in order to generate relevant indicator weights.

In addition to the sources identified from the scientific literature, guidelines and standards such as the "GRI G4 Reporting Guidelines" by the Global Reporting Initiative [51], the "Conflict Minerals Reporting Template" [52] and the "Sustainable Development progress metrics for process industries" by the Institution of Chemical Engineers (IChem) [53] were also considered as a basis for indicator development. As can be seen in Table 1, ten additional guidelines and standards were considered that were mainly identified via the interviews with industrial experts. These 19 sources entered the third research step, the collection of indicators.

Table 1. Initial sources for the indicator development $(n=19)$.

\begin{tabular}{|c|c|}
\hline Type of Publication & Source \\
\hline Peer-reviewed articles (9) & $\begin{array}{l}\text { Howarth and Hadfield [54], Salvado et al. [49], Veleva and Ellenbecker [24], } \\
\text { Chen and Xiu [50], Hanson and Holt [48], Adhitya et al. [55], Ahi and } \\
\text { Searcy [17], Genovese et al. [46], Wang et al. [47] }\end{array}$ \\
\hline Guidelines/Standards (10) & $\begin{array}{l}\text { Global Reporting Initiative (GRI) [51], Electronic Industry Citizenship } \\
\text { Coalition (EICC) [5] EICC [56] Supplier Ethical Data Exchange } \\
\text { (SEDEX) [57], Electric Utility Industry Sustainable Supply Chain Alliance } \\
\text { (EUI SSCA) [53], Institution of Chemical Engineers (IChem) [58], } \\
\text { United Nations [59], Conflict Free Sourcing Initiative [52], } \\
\text { European Commission [9], OHSAS Project Group [60] }\end{array}$ \\
\hline
\end{tabular}

\subsection{Collection of Indicators}

In the third research step, the sources listed in Table 1 were analyzed by means of a content analysis and indicators were assigned to their respective aspects of supply chain sustainability.

Figure 3 illustrates the structure which was used for grouping the indicators according to the 36 supply chain sustainability aspects described by Fritz et al. [18]. This structure is based on Clift [22], who suggests it is useful to proceed from broad categories via definite aspects and on to specific indicators, for example, as is done by the Global Reporting Initiative in their reporting guidelines [51]. The sustainability dimensions derive from the definition of sustainability given by the Brundtland Report, which ensures a triple-bottom-line approach in conducting a sustainability assessment with the suggested indicators $[25,26]$. The categories define broader areas of economic, environmental and social issues such as human rights, emissions or materials. Sustainability aspects refer to more specific issues in these categories such as energy consumption, waste management, conflict minerals, or stakeholder inclusiveness.

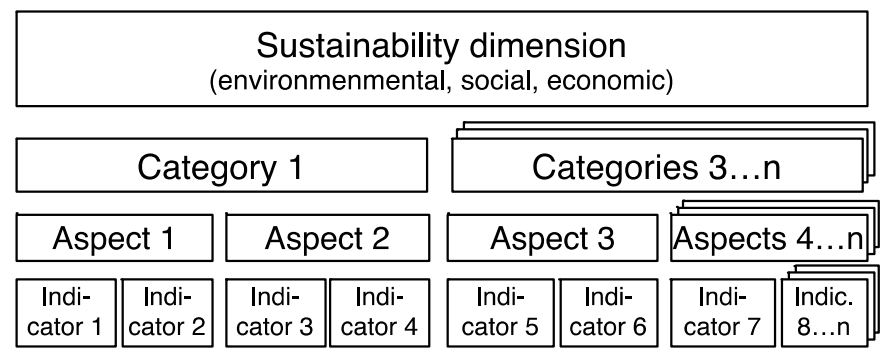

Figure 3. Structure for grouping the collected indicators.

By adopting this structure, a strong and transparent link of each indicator to a single sustainability aspect, to a broader category, and to an underlying dimension of sustainability was ensured. This facilitates reproducibility of results, for instance, when similar indicators are to be defined for another industrial sector. In such a case, the 115 supply chain sustainability aspects and categories identified by Fritz et al. [18] could be used as a basis for assessing their relevance and applicability for the industrial sector under consideration, as well as for identifying and defining the appropriate indicators. 
When grouping the indicators, a distinction was made between qualitative and quantitative indicators and between supply chain level (e.g., percent of suppliers with environmental education programs for employees, suppliers, and customers [57]), company level (e.g., percent of workers employed that are temporary contract workers ([5]) and product/part level indicators (e.g., materials used per unit of product [24]). The qualitative indicators combine dichotomous indicators such as yes/no questions with those indicators that need a text description. The group of quantitative indicators comprised ratios and amounts. The result of the third research step was a categorized list of 463 sustainability indicators.

Out of these indicators, $87 \%$ focused on assessing sustainability at company level. Out of the indicator sources listed in Table 1 only the following sources encompass particular supply chain-related sustainability indicators: [24,51,57]. This emphasizes the need for specific supply chain sustainability indicators. Furthermore, the majority (65\%) of indicators extracted from the sources are of a qualitative nature. As can be seen in Figure 4, this is mainly due to the particular focus placed on the social and governance topics of sustainability.

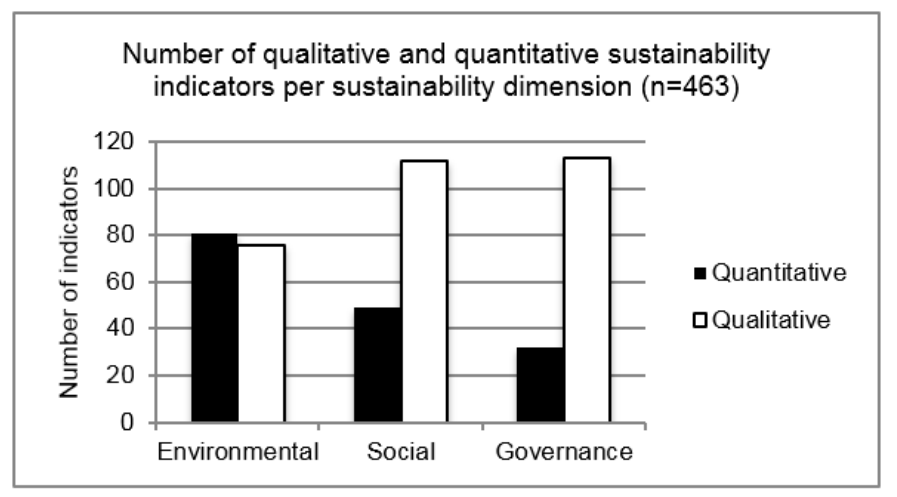

Figure 4. Number of qualitative and quantitative indicators used as basis for the indicator developed per sustainability dimension $(n=463)$.

\subsection{Development and Adaptation of Indicators}

In the fourth step of the research process, the list of 463 sustainability indicators was condensed by deleting redundancies and by selecting and adapting for each of the 36 sustainability aspects at least one indicator. New indicators were developed for aspects for which there were no basis in the literature. As indicated in Section 3, the fourth research step consisted in an iterative process of desk research and focus group workshops with industry experts. This was needed in order to integrate the indicators with the ASSC framework, to adapt them to a supply chain focus, and to meet industrial and technical requirements for a supply chain-wide sustainability assessment.

\subsubsection{Consideration of Industrial Requirements}

Schöggl et al. [12] identified the following seven industrial requirements for supply chain-wide sustainability assessment: (1) accessibility for companies inexperienced in sustainability assessment; (2) applicability with respect to different types of sustainability data; (3) applicability in supply chain-wide assessment; (4) adaptability to supply chain dynamics; (5) adaptability to regional and cultural characteristics; (6) comparability of results; and (7) robustness in the face of insufficient information.

The majority of these seven requirements, namely requirements (2), (3), (4), (6) and (7), were addressed by integrating the indicators into the ASSC framework and adapting them in order to allow for the application of the proposed methods in aggregating the sustainability information of suppliers into different supply chain KPIs. Regarding point (3), applicability in supply chain-wide assessment, the indicators were adapted such that they could be used for collecting and aggregating standardized sustainability information provided by supply chain partners, optionally via a software-based exchange 
(see Section 6.1). In order to address requirement (1), accessibility for companies inexperienced in sustainability assessment, quantitative and qualitative indicators were provided for each aspect of sustainability (as can be seen in Table 2). Requirement (5), adaptability to regional and cultural characteristics, was addressed by focusing on the specifications of the European automotive and electronics industries via the selection of sources, as in Fritz et al. [18] as a basis for the various aspects of sustainability, and by the integration of European industry experts via the interviews and focus groups.

Table 2. Categorization of the supply chain sustainability indicators $(n=69)$.

\begin{tabular}{cccc}
\hline & \multicolumn{3}{c}{ Type of Indicator } \\
\hline & $\begin{array}{c}\text { Governance } \\
\text { (Qualitative) }\end{array}$ & $\begin{array}{c}\text { Commitment } \\
\text { (Qualitative) }\end{array}$ & $\begin{array}{c}\text { Performance } \\
\text { (Quantitative) }\end{array}$ \\
\hline Compliance & 4 & - & 8 \\
Management & 6 & - & 6 \\
systems & - & 6 & 16 \\
Environmental & - & 10 & 13 \\
Social & 10 & 16 & 43 \\
Total & & &
\end{tabular}

\subsubsection{Consideration of Technical Requirements}

Grambow et al. [61] identify the following seven challenges of collecting sustainability data throughout supply chains: (1) dynamic selection of involved parties; (2) access to requested data; (3) meta data management; (4) request variants; (5) incompleteness and quality; (6) monitoring; and (7) run time variability. Although these challenges can mainly be addressed technically, the following points do have to be considered during the indicator development phase since the choice of indicators determines which sustainability data are exchanged.

Challenge 1 refers to the problem that collecting sustainability data supply chain-wide requires information from various partners, and that these are subject to change over time. Challenge 2 refers to the problem that these partners might range from SMEs to multinational corporations, which might be more or less experienced with collecting and more or less willing to provide the requested information. Both challenges are addressed by integrating the sustainability indicators into the ASSC framework outlined in Section 2.1. In doing so, the indicators were designed to be dynamic in nature (e.g., total indicator values can be allocated either to organizations, products or parts) and to be applicable under conditions of limited information by facilitating not only full supply chain-wide but also multi or only bilateral assessments. This means that in the likely case of incomplete information with respect to the entire supply chain, the suggested indicator topics can, for instance, be used in assessing the indicator values from accessible supply chain members by asking for respective company level values (e.g., with respect to total $\mathrm{CO}_{2}$ emissions) without assigning them to a full product life cycle. The supply chain KPIs are flexible regarding a change of one or more supply chain partners, since their indicator values can be integrated into those KPIs already assessed. Challenge 5 , the incompleteness and quality of sustainability data, can be dealt with by applying a range of suitable plausibility checks [12].

The development process of the set of indicators was considered finished when the focus group workshops did not lead to further requirements and indicators. After this point a final workshop with a group of 13 industry experts was conducted in which the final 69 indicators were validated and three indicators selected, for implementation and testing in a software prototype for sustainability data exchange (see Section 6). In this final workshop, a portfolio analysis matrix was used to furthermore group the 69 into core and additional indicators according to their practical relevance as inspired by [24].

\section{Supply Chain Sustainability Indicators}

The five-step research process described above enabled the following set of 69 supply chain sustainability indicators for the European automotive and electronics industries to be compiled. 
As can be seen in Table 2, out of the 69 indicators, 26 are qualitative governance (10) or commitment (16) indicators. In total, 43 are quantitative performance indicators, categorized into compliance (8), management systems (6), environmental (16) and social (13). As can be seen in Table 3, the indicators were integrated into the structure of the ASSC framework shown in Figure 1, providing for the majority of the sustainability aspects (column 1) one qualitative governance or commitment indicator (column 2) and one or more quantitative performance indicators (columns 3-5).

As stated in Section 4.3.1, the provision of simple qualitative indicators alongside quantitative indicators is meant to increase the accessibility for companies inexperienced in sustainability assessment (industrial requirement 1). More specifically, the qualitative compliance indicators reflect the legal pressures and their importance in sustainability assessment in general and in the two target industries in particular. Similar, the indicators on management systems and standards reflect their important role as SSCM practice. The qualitative commitment indicators can be understood as entry level indicators, which signal a supplier's knowledge about an issue and their commitment to engage on it. For the data requesting company, a positive answer to such an indicator could be the starting point for further actions (e.g., supplier training, integration into audit schemes, etc.). The improvement process could furthermore be measured with the corresponding quantitative performance indicators.

Table 3. Examples of the supply chain sustainability indicators (see Table S1 in the Supplementary Material for a full list of indicators). Italics = additional indicators.

\begin{tabular}{|c|c|c|c|c|}
\hline \multirow{2}{*}{ Aspect } & \multirow{2}{*}{$\begin{array}{l}\text { Environmental } \\
\text { Commitment Level }\end{array}$} & \multicolumn{3}{|c|}{ Environmental Performance Level } \\
\hline & & Indicator & Equation & Unit \\
\hline $\begin{array}{l}\text { Hazardous } \\
\text { substances }\end{array}$ & $\begin{array}{l}\text { Are you committed to the } \\
\text { avoidance of hazardous } \\
\text { substances in products? }\end{array}$ & $\begin{array}{l}\text { Substances of Very High } \\
\text { Concern (SVHC) }\end{array}$ & $\begin{array}{l}\text { Total amount of } \\
\text { each SVHC }\end{array}$ & $\mathrm{kg}$ \\
\hline \multirow[t]{2}{*}{$\begin{array}{l}\text { Wastes } \\
\text { management }\end{array}$} & $\begin{array}{l}\text { Are you committed to } \\
\text { waste management } \\
\text { (e.g., prevention, reduction, } \\
\text { reuse, safe disposal)? }\end{array}$ & $\begin{array}{l}\text { Total amount of solid wastes } \\
\text { generated by type }\end{array}$ & $\begin{array}{l}\sum \text { Solid wastes } \\
\text { produced and } \\
\text { generated by type }\end{array}$ & $\mathrm{kg}$ \\
\hline & & $\begin{array}{l}\text { Total amount of solid wastes } \\
\text { reused, recycled, } \\
\text { landfilled per type }\end{array}$ & $\begin{array}{l}\sum \text { Solid wastes } \\
\text { reused, recycled, } \\
\text { landfilled per type }\end{array}$ & $\mathrm{kg}$ \\
\hline \multirow[t]{4}{*}{$\begin{array}{l}\text { GHG and } \\
\text { other air } \\
\text { emissions }\end{array}$} & $\begin{array}{c}\text { Are you committed towards } \\
\text { the reduction and } \\
\text { prevention of GHG and } \\
\text { other air emissions? }\end{array}$ & $\begin{array}{c}\text { Total direct and indirect } \\
\text { GHG-emissions from energy } \\
\text { demand (Scope } 1 \text { and } 2 \\
\text { according to GHG-protocol) }\end{array}$ & $\sum \mathrm{CO}_{2}$ equivalent & $\begin{array}{l}\mathrm{kg} \text { of } \mathrm{CO}_{2} \\
\text { equivalent }\end{array}$ \\
\hline & & $\begin{array}{c}\text { Other relevant indirect emissions } \\
\text { by weight (Scope } 3 \text { according to } \\
\text { the GHGs protocol) }\end{array}$ & $\sum \mathrm{CO}_{2}$ equivalent & $\begin{array}{l}\mathrm{kg} \text { of } \mathrm{CO}_{2} \\
\text { equivalent }\end{array}$ \\
\hline & & $\begin{array}{l}\text { Emissions of ozone-depleting } \\
\text { substances by weight }\end{array}$ & $\sum C F C-11$ equivalent & $\begin{array}{c}\text { kg of CFC-11 } \\
\text { equivalent }\end{array}$ \\
\hline & & $\begin{array}{l}N O_{x}, S O_{x} \text { and other significant } \\
\text { air emissions by type and weight }\end{array}$ & $\begin{array}{l}\sum N O_{x}, \sum S O_{x}, \sum \\
\text { Other significant air } \\
\text { emissions by type }\end{array}$ & $k g$ \\
\hline
\end{tabular}

In the following, a brief overview of the indicators and the corresponding tables for performance indicators is provided for each of the four categories "Compliance", "Management systems and Standards", "Environment", and "Social". This overview provides more details on how and why certain indicators were adapted based on the 463 sources, and which were newly developed. The full list of indicators can be found in Table S1 in the Supplementary Material.

\subsection{Governance Indicators}

The governance indicators form the basis for the assessment since this category comprises indicators related to sustainability aspects from "compliance" (Section 5.1.1) and the "management systems and standards" (Section 5.1.2) groups. As the workshops with industry experts revealed, 
these groups of indicators are essential for assessing the sustainability performance of supply chain partners. This is in line with Diabat and Govindan [6] who identify "government regulations" and the "certification of suppliers' environmental management systems" as the main drivers for SSCM, and also complies with the findings of Beske and Seuring [62] who show that "Standards and certifications" play a vital role in improving supply chain sustainability performance. Standards and certification, as encompassed in the governance indicators, can easily be used to solve risk-related issues, to add legitimacy to a business and to build and maintain sustainability-related performance measurement systems $[16,63,64]$. In such a performance measurement system, the performance indicators from the environmental and social dimension outlined in Sections 5.2 and 5.3 may be used.

\subsubsection{Compliance}

For each of the four compliance-related sustainability aspects listed in Table 4, a qualitative and quantitative indicator is provided. As qualitative indicators, four questions relating to compliance with a specific environmental, social, human rights and product-related regulation were suggested (see Table S1 in the Supplementary Material). The EICC [5] and the EUI SSCA [57] follow similar approaches. As performance indicators the total amount of fines and incidents for non-compliance were selected as illustrated in Table 4. These indicators are adaptations from the GRI G4 guidelines [51].

Table 4. Supply chain performance indicators for the governance level.

\begin{tabular}{ccccc}
\hline Sustainability Aspect [18] & Performance Indicators & Equation & Unit & Sources \\
\hline $\begin{array}{c}\text { Compliance with environmental, } \\
\text { social, human rights, product } \\
\text { related regulations }\end{array}$ & $\begin{array}{c}\text { Fines due to non-compliance } \\
\text { with the respective regulations }\end{array}$ & $\begin{array}{c}\text { Total value } \\
\text { of fines }\end{array}$ & $€$ & {$[5,51,57]$} \\
\hline $\begin{array}{c}\text { Incidents due to } \\
\text { non-compliance with the } \\
\text { respective regulations }\end{array}$ & $\begin{array}{c}\text { Total number } \\
\text { of incidents }\end{array}$ & Number & {$[5,51,57]$} \\
\hline
\end{tabular}

\subsubsection{Management Systems and Standards}

For the five sustainability aspects related to sustainability-oriented management systems, five qualitative indicators (fixed-alternative questions for the availability of the specific system with the option to provide a text description) were suggested. In the workshops it was agreed that the number of days since a self-assessment or an external audit had been conducted could be used as a proxy for the vigor and effectiveness of the management system in place. These were therefore chosen as performance indicators for the five sustainability aspects related to management systems as illustrated in Table 5. For the aspect "Stakeholder inclusiveness" a variety of qualitative indicators but no quantitative indicator could be found in the literature review. Hence, the suggested quantitative indicators serve as a starting point, and if necessary, may be adapted to the specific needs of a company that is assessing the sustainability performance of its supply chain.

Table 5. Supply chain performance indicators on management systems and standards. Italic = additional indicator.

\begin{tabular}{|c|c|c|c|c|}
\hline Sustainability Aspect [18] & Performance Indicators & Equation & Unit & Sources \\
\hline \multirow[t]{2}{*}{$\begin{array}{l}\text { Environmental; Social; } \\
\text { Quality; Health and safety } \\
\text { management system }\end{array}$} & $\begin{array}{l}\text { Monitoring of the } \\
\text { management system via } \\
\text { self-assessment or audit }\end{array}$ & $\begin{array}{c}\text { Number of days since last } \\
\text { self-assessment }\end{array}$ & Days & - \\
\hline & & $\begin{array}{c}\text { Number of days since } \\
\text { last audit? }\end{array}$ & Days & - \\
\hline Stakeholder inclusiveness & $\begin{array}{l}\text { Conducted stakeholder } \\
\text { mapping and active } \\
\text { stakeholder engagement }\end{array}$ & $\begin{array}{l}\text { Number of stakeholder } \\
\text { dialogues per year }\end{array}$ & Number & - \\
\hline Sustainable R\&D & $\begin{array}{c}\text { R\&D expenses related to } \\
\text { sustainability }\end{array}$ & $\begin{array}{c}\text { R\&D expenses related to } \\
\text { sustainability/ } \\
\text { Total R\&D expenses }\end{array}$ & $\%$ & {$[49,57]$} \\
\hline
\end{tabular}




\subsection{Environmental Indicators}

For the environmental performance indicators listed in Table 6, the literature provided the most comprehensive basis of quantitative indicators. Thus, the development phase outlined in Section 4.3 mainly focused first on selecting and adapting indicators for each environmental aspect from a variety of similar indicators, and second, on adapting and integrating them into the ASSC framework. The indicators concerning the aspect "biodiversity", for instance, are adaptations of the GRI indicators, which ask for descriptions of impacts and measures. The environmental commitment indicator checks whether such a description of impacts and measures is available.

Table 6. Environmental supply chain performance indicators. Italic = additional indicators. \# = Number.

\begin{tabular}{|c|c|c|c|c|}
\hline \multirow{2}{*}{$\begin{array}{l}\text { Sustainability } \\
\text { Aspect [18] }\end{array}$} & \multicolumn{4}{|c|}{ Environmental Performance Level } \\
\hline & Performance Indicator & Equation & Unit & Sources \\
\hline $\begin{array}{l}\text { Hazardous } \\
\text { substances }\end{array}$ & $\begin{array}{l}\text { Substances of Very High } \\
\text { Concern (SVHC) }\end{array}$ & Total amount of each SVHC & $\mathrm{kg}$ & {$[24,57]$} \\
\hline \multirow[t]{2}{*}{$\begin{array}{c}\text { Waste } \\
\text { management }\end{array}$} & $\begin{array}{l}\text { Total amount of solid wastes } \\
\text { generated by type }\end{array}$ & $\begin{array}{l}\sum \text { Solid wastes produced and } \\
\text { generated by type }\end{array}$ & $\mathrm{kg}$ & {$[24,51]$} \\
\hline & $\begin{array}{l}\text { Total amount of solid wastes reused, } \\
\text { recycled, landfilled per type }\end{array}$ & $\begin{array}{c}\sum \text { Solid wastes reused, recycled, } \\
\text { landfilled per type }\end{array}$ & $\mathrm{kg}$ & {$[24,51,56,57]$} \\
\hline \multirow[t]{4}{*}{$\begin{array}{l}\text { GHG and other } \\
\text { air emissions }\end{array}$} & $\begin{array}{c}\text { Total direct and indirect } \\
\text { GHG-emissions from energy } \\
\text { demand (Scope } 1 \text { and } 2 \text { according } \\
\text { to GHG-protocol) }\end{array}$ & $\sum \mathrm{CO}_{2}$ equivalent & $\mathrm{kg}$ & {$[24,51]$} \\
\hline & $\begin{array}{c}\text { Other relevant indirect emissions by } \\
\text { weight (Scope } 3 \text { according to } \\
\text { the GHG-protocol) }\end{array}$ & $\sum \mathrm{CO}_{2}$ equivalent & $k g$ & {$[24,51]$} \\
\hline & $\begin{array}{l}\text { Emissions of ozone-depleting } \\
\text { substances by weight }\end{array}$ & $\sum C F C-11$ equivalent & $\mathrm{kg}$ & {$[24,51]$} \\
\hline & $\begin{array}{c}\mathrm{NO}_{x}, \mathrm{SO}_{x} \text { and other significant air } \\
\text { emissions by type and weight }\end{array}$ & $\begin{array}{c}\sum N O_{x}, \sum S O_{x}, \sum \text { Other significant air } \\
\text { emissions by type }\end{array}$ & $\mathrm{kg}$ & {$[24,51]$} \\
\hline \multirow[t]{2}{*}{$\begin{array}{c}\text { Energy } \\
\text { consumption }\end{array}$} & Energy consumption & $\begin{array}{l}\text { Total energy consumption (incl. } \\
\text { self-generated and purchased) }\end{array}$ & Joules & {$[24,51]$} \\
\hline & Renewable energy sources & $\begin{array}{l}\text { Total amount of renewable energy per } \\
\text { source (solar, wind, ocean, hydro-power, } \\
\text { hydrogen from renewable sources, } \\
\text { biofuels, geothermal, biomass) }\end{array}$ & Joules & {$[24,51]$} \\
\hline \multirow[t]{3}{*}{ Materials } & Use of renewable materials & $\begin{array}{l}\text { Weight of materials that are } \\
\text { renewable/Total weight of materials }\end{array}$ & $\%$ & [24] \\
\hline & Use of recycled materials & $\begin{array}{l}\text { Weight of materials that are recycled } \\
\text { material/Total weight of materials }\end{array}$ & $\%$ & [24] \\
\hline & Recyclability of the product & $\begin{array}{c}\text { Total weight of recyclable materials/Total } \\
\text { weight of materials }\end{array}$ & $\%$ & [24] \\
\hline \multirow[t]{2}{*}{ Water } & Total use of water per year & Total use of water/year & $\%$ & [24] \\
\hline & Reuse of water & Water reused/Total use of water & $\%$ & {$[24]$} \\
\hline \multirow[t]{2}{*}{ Biodiversity } & $\begin{array}{l}\text { Number of identified impacts } \\
\text { on biodiversity }\end{array}$ & Total number of impacts identified & $\#$ & [51] \\
\hline & $\begin{array}{c}\text { Number of measures to reduce } \\
\text { identified impacts }\end{array}$ & $\begin{array}{c}\text { Total number of measures to reduce } \\
\text { identified impacts }\end{array}$ & $\#$ & [51] \\
\hline
\end{tabular}

\subsection{Social Indicators}

For the social dimension, in the course of workshops, different approaches for the quantification of social supply chain sustainability aspects were discussed and the following indicators developed or adapted from the literature. As can be seen in Table 7, the only aspect for which the literature provided no basis for indicator development was "Confidentiality of data". 
Table 7. Social supply chain performance indicators. Italic $=$ additional indicators. \# = Number.

\begin{tabular}{|c|c|c|c|c|}
\hline \multirow[b]{2}{*}{ Sustainability Aspect [18] } & \multicolumn{4}{|c|}{ Social Performance Level } \\
\hline & $\begin{array}{l}\text { Performance } \\
\text { Indicator }\end{array}$ & Equation & Unit & Sources \\
\hline Corruption and bribery & Incidents of corruption & $\sum$ Incidents of corruption & $\#$ & {$[5,51,56]$} \\
\hline Child labors & Incidents of child labor & $\sum$ Incidents of child labor & $\#$ & {$[5,51,56]$} \\
\hline \multirow[t]{6}{*}{$\begin{array}{l}\text { Occupational Health } \\
\text { and Safety }\end{array}$} & $\begin{array}{l}\text { Injuries, occupational } \\
\text { diseases, lost days, } \\
\text { absenteeism } \\
\text { and fatalities }\end{array}$ & $\begin{array}{l}\text { (Total number of injuries } \times \text { working hours } \\
\text { per week } \times \text { working weeks)/Total amount of } \\
\text { hours worked by all employees per year }\end{array}$ & $\%$ & {$[56,60]$} \\
\hline & & $\begin{array}{l}\text { (Total number of occupational diseases cases } \times \\
\text { working hours per week } \times \text { working weeks)/Total } \\
\text { amount of hours worked by all employees per year }\end{array}$ & $\%$ & {$[24,51,60]$} \\
\hline & & $\begin{array}{l}\text { (Total number of lost days } \times \text { working hours } \\
\text { per week } \times \text { working weeks)/Total amount of } \\
\text { hours worked by all employees per year }\end{array}$ & $\%$ & {$[24,51,60]$} \\
\hline & & $\begin{array}{c}\text { (Total number of missed (absentee) days over the } \\
\text { period } \times \text { working hours per week } \times \text { working } \\
\text { weeks)/Total amount of hours worked by all } \\
\text { employees per year }\end{array}$ & $\%$ & {$[24,51,60]$} \\
\hline & & $\begin{array}{l}\text { (Total number of fatalities } \times \text { working hours } \\
\text { per week } \times \text { working weeks)/Total amount of } \\
\text { hours worked by all employees per year }\end{array}$ & $\%$ & {$[24,51,60]$} \\
\hline & $\begin{array}{l}\text { Employees receiving } \\
\text { OHS training }\end{array}$ & $\begin{array}{l}\text { Total number of trained employees on } \\
\text { OHS/Total number of employees }\end{array}$ & $\%$ & [56] \\
\hline Employee training & $\begin{array}{l}\text { Training per employee } \\
\text { per year }\end{array}$ & $\begin{array}{l}\text { Total training hours/ } \\
\text { Total number of employees }\end{array}$ & $\%$ & [51] \\
\hline Non-discrimination & $\begin{array}{l}\text { Incidents of } \\
\text { discrimination }\end{array}$ & $\begin{array}{l}\text { Total number of incidents of discrimination/ } \\
\text { Total number of employees }\end{array}$ & $\%$ & [51] \\
\hline Use of conflict minerals & Conflict minerals used & $\begin{array}{l}\text { Amount of Tantalum, Tin, Tungsten, } \\
\text { Gold used }\end{array}$ & $\mathrm{kg}$ & [52] \\
\hline Securing minimum wages & $\begin{array}{l}\text { Employees covered by } \\
\text { minimum wages }\end{array}$ & $\begin{array}{l}\text { Total number of employees covered by at } \\
\text { least the legal local minimum wages/ } \\
\text { Total number of employees }\end{array}$ & $\%$ & [56] \\
\hline Confidentiality of data & Confidentiality of data & $\begin{array}{l}\sum \text { Conflicts regarding disclosure of } \\
\text { confidential data }\end{array}$ & $\#$ & - \\
\hline \multirow[t]{2}{*}{$\begin{array}{l}\text { Freedom of association and } \\
\text { collective bargaining, } \\
\text { protection of worker's } \\
\text { representatives }\end{array}$} & $\begin{array}{l}\text { Freedom of association } \\
\text { and collective } \\
\text { bargaining }\end{array}$ & $\begin{array}{l}\text { Number of incidents of violations of freedom } \\
\text { of association }\end{array}$ & $\#$ & [51] \\
\hline & $\begin{array}{l}\text { Employees covered by } \\
\text { collective bargaining } \\
\text { agreements }\end{array}$ & $\begin{array}{c}\text { Total number of employees covered by collective } \\
\text { bargaining agreements/Total number of } \\
\text { all employees }\end{array}$ & $\%$ & [51] \\
\hline Community engagement & $\begin{array}{l}\text { Expenses for local } \\
\text { community projects } \\
\text { and donations }\end{array}$ & $\sum$ Expenses & $€$ & [24] \\
\hline Gender awareness & $\begin{array}{l}\text { Female employees in } \\
\text { the company }\end{array}$ & $\begin{array}{l}\text { Total number of female employees / } \\
\text { Total number of employees }\end{array}$ & $\%$ & [51] \\
\hline
\end{tabular}

\section{Case Example}

This section provides a case example showing how the set of 69 indicators may be integrated into supply chain data exchange software and how the maturity of supply chain sustainability data exchange in the automotive and electronics industries was estimated.

\subsection{Sustainability Data Exchange Hub}

From a practical perspective, the set of indicators presented above is an important constituent for facilitating supply chain sustainability assessment. It addresses the challenge of supply chain 
sustainability assessment by defining which data should be assessed, and how, in specific industries. This is illustrated in Figure 5 under data challenges. The indicator set complements previous work on the data challenges, namely, on the aspects of sustainability, the ASSC framework, the aggregation methods and the plausibility checks $[12,18]$. Since products in the automotive and electronics industries consist of a large number of individual components and sub-components, supply chain sustainability assessment requires the collection of heterogeneous sustainability data throughout intertwined and non-transparent supply chains [61]. These highly complex, cross-organizational data collection processes pose further technical and organizational challenges that need to be addressed.

Organizational challenges are linked to all company activities which require and provide information on the different sustainability indicators, such as alignment with company strategies, information collection in different departments, indicator calculation or intra- and inter-organizational communication. Technical challenges occur due to the need for exchanging sustainability information between supply chain partners and are related to aspects of internal and external data management (e.g., integration into existing product lifecycle management (PLM) and product data management systems (PDM)), as briefly outlined in Section 4.3.2 and discussed in more detail by Grambow et al. [61].
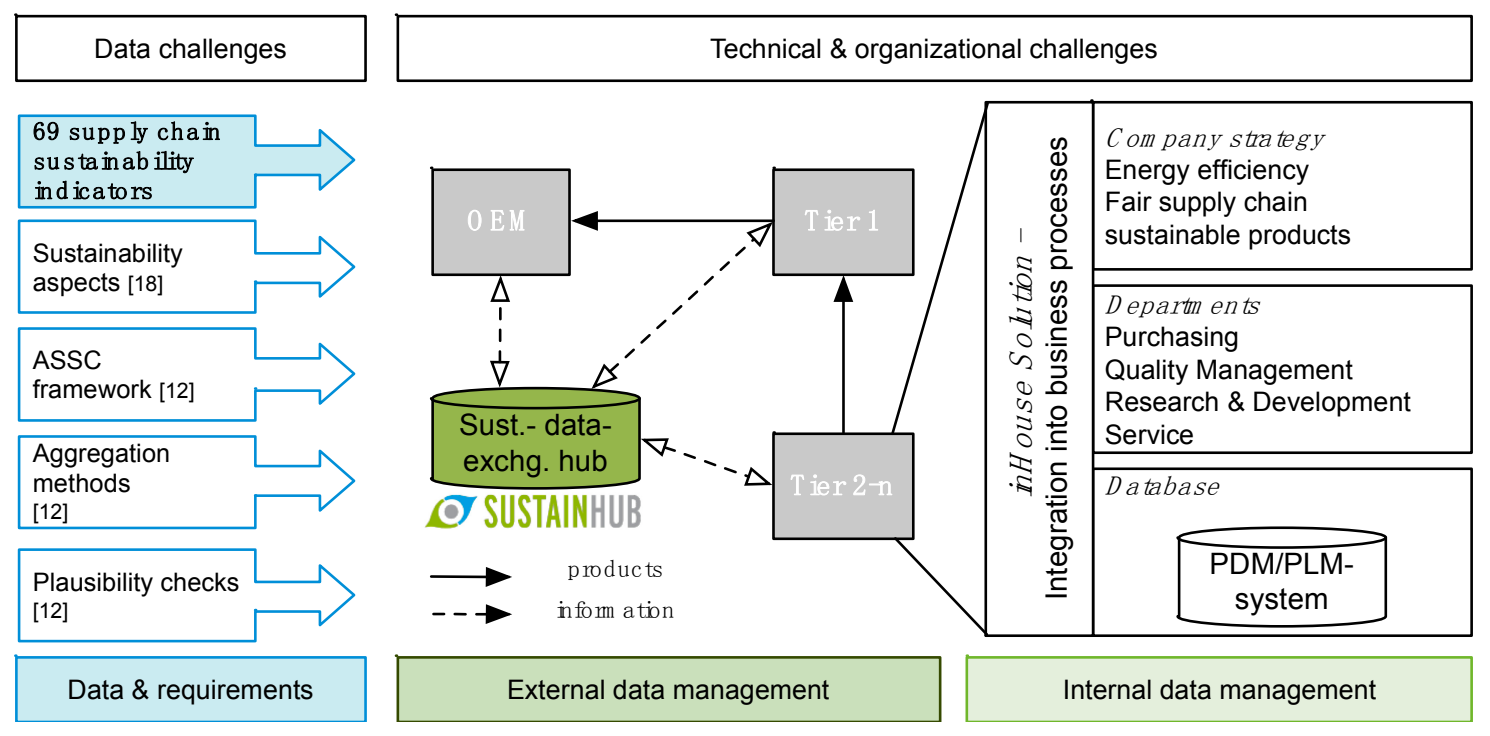

Figure 5. Supply chain data exchange hub (own illustration based on $[65,66]$ ). PDM/PLM = Product Data Management System/Product Life Cycle Management System.

One approach to addressing these three challenges is the use of a data exchange hub for sustainability information, as was developed in the course of the research project "Sustainability data exchange hub-SustainHub" [65,66]. Figure 5 provides an overview of the general outline of the SustainHub approach. This approach addresses a standardized exchange of sustainability information along supply chains that is organized centrally via the so-called "SustainHub". The main advantage of such an exchange hub lies in the resulting increased efficiency of the work processes and thus in the reduced costs for collecting and exchanging sustainability information along a supply chain [67]. Any supply chain partners asked to provide sustainability information only need to assess and report on sustainability indicators once [66]. This is particularly relevant for small and medium sized companies (SMEs), which, although resource-constrained, constitute more than $99 \%$ of the companies in the EU [68]. Furthermore, via the data exchange hub, sustainability information could be provided to all requesting companies (e.g., all customers of the information-providing company), given that they have access permission.

This data procedure was tested with respect to the three indicators "Gender awareness", "Energy consumption" and "Hazardous substances" using a software-prototype of a sustainability data 
exchange hub. The test was conducted by industry practitioners who evaluated both technical and practical aspects of the procedure. For each of the three indicators, the options for data entry were specified according to the rational of providing compliance and commitment indicators alongside quantitative performance indicators.

\subsection{Maturity of Sustainability Data Exchange}

In order to further reflect upon the results of this paper in the context of the European automotive and electronics industries, this section is intended to show the extent to which sustainability data are currently being exchanged on the 69 indicators. This entailed analyzing which indicators are covered by which standards and templates for data collection and exchange (see Table S2 in the Supplementary Material).

Figure 6 illustrates the results of the analysis. The $x$-axis refers to the extent to which sustainability data are exchanged along a supply chain as well as to the degree of standardization of such an exchange. The $y$-axis distinguishes between exchange at the product level and at the organizational level. This is meant to draw attention to the fact that collecting and exchanging sustainability data at the product level may require more information than at the organizational level since the respective sustainability data (e.g., GHG-emissions) have to be allocated additionally to each product separately. As some indicators are exchanged at both the organizational and product level, the overview comprises 74 rather than 69 indicators.

For indicators in the first segment from the left, no exchange between companies was identified, only the mere reporting of the sustainability indicator (e.g., via a sustainability report). One example for this are the indicators suggested for biodiversity. These can be linked to the standardized sustainability indicators of the Global Reporting Initiative (GRI). The second segment comprises indicators for which only bilateral exchange between two companies in a supply chain was identified. The third and fourth segments comprise sustainability indicators for which an exchange throughout the supply chain was identified. These are differentiated in terms of "semi-structured" and "fully structured" sustainability data exchange.

Semi-structured sustainability data exchange refers to indicators for which no standardized data templates could be identified, but for which some indication of a full supply chain exchange could be found. This includes, for example, indicators related to the energy consumption of a company, since such information is already required for life cycle assessment based on primary data. Further examples include the standardized data exchange on social sustainability aspects via SEDEX with the Sedex Members Ethical Trade Audit (SMETA) template or the EICC-GeSI template used for reporting on conflict minerals $[52,58]$. Both provide a standardized exchange template but are not consistently used throughout the industry.

The highest level of standardization within sustainability data exchange refers to clearly defined (fully structured) data exchange templates, since these are accepted throughout the industries. The most mature level of sustainability data exchange standardization within the electronics and automotive industry is related to "material declaration" issues. Regulations such as RoHS, ELV and REACH have led to concerted efforts in the electronics and automotive industries to create standards on what kind of data needs to be exchanged in order to comply with legal requirements. The automotive industry uses the most consistent data exchange system (IMDS, International Material Data System) in order to fulfill the requirements of the ELV Directive. The underlying data model is highly standardized and is accepted throughout the industry. Within the electronics industry, the situation is somewhat more diverse. Regarding "material declaration", there are two main standards in place: the IPC 1752 and the IEC 62474 .

As can be seen in Figure 6, data exchange currently takes place mainly at the organizational level on a bilateral and a semi-structured basis. Only for six indicators-which are all material-related-does a fully structured exchange take place along the supply chain. On the other hand, only for 10 out of the 74 indicators could no indication of a data exchange be found. 


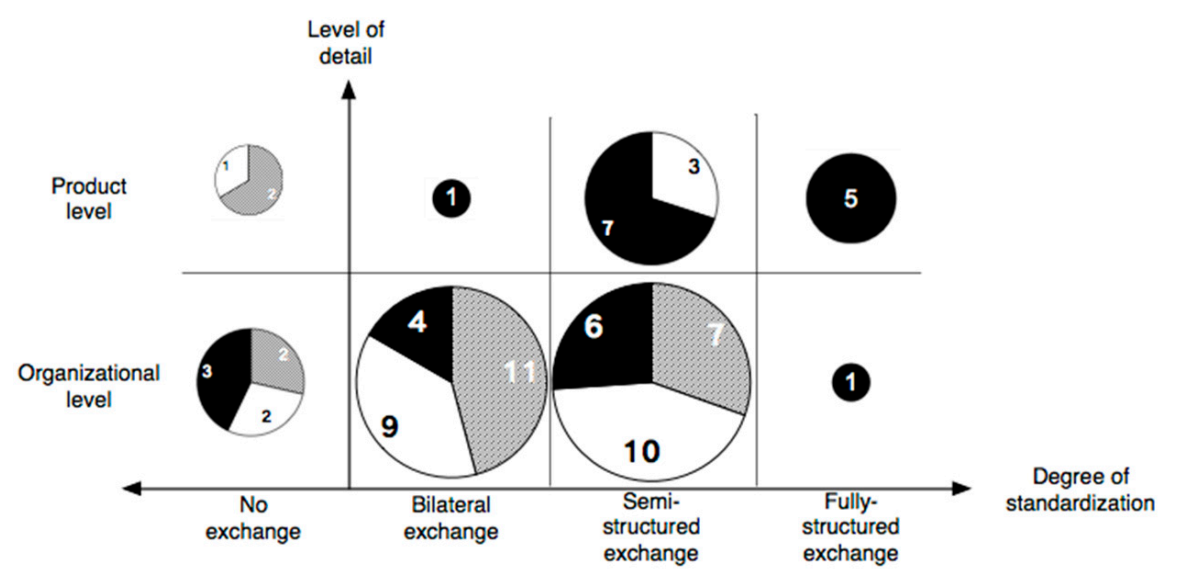

Figure 6. Maturity of sustainability data exchange in the automotive and electronics industries $(n=74)$. Black = environmental indicators; shaded gray = social indicators; white = governance indicators.

The analysis revealed that topics related to material compliance are a particular focus of supply chain sustainability data exchange. Furthermore, it can be confirmed that some form of reporting is undertaken for all of the proposed 69 supply chain sustainability indicators (10). For the majority of indicators (64), either a bilateral form of exchange or a full supply chain exchange was identified. Hence, one may safely conclude that the set of proposed indicators offers considerable potential with respect to the possibility of intensifying future data exchange. This is indicated by the variety of semi-structured and bilateral data exchange standards that cover the indicator issues addressed.

\section{Conclusions and Discussion}

The present paper suggests the use of a set of 69 supply chain sustainability indicators for the European automotive and electronics industries. This set of indicators was drawn up on the basis of a systematic literature review, 13 interviews and five focus group workshops, all conducted with industry experts.

The literature review revealed that while a few sets of supply chain sustainability indicators are available, none of them is suitable from a comprehensive, life-cycle-oriented, perspective of sustainability. They either tend to neglect the social dimension, and/or lack the specificity needed to analyze the two target industries. Hence, the guidelines and standards identified in the expert interviews also needed to be taken into consideration when developing the set of indicators.

The set of indicators facilitates the tracing, not only of general environmental aspects such as energy and material flows, but also of social sustainability topics along a supply chain. The indicators' level of detail ranges from qualitative compliance information to detailed values for an in-depth performance assessment on a company or product level (e.g., carbon, water or energy footprint). This thus offers the potential to foster the monitoring and decision-making in sustainable supply chain management. In light of the current literature, the main contribution of this paper is that it provides the foundation for a supply chain sustainability management, which is based on real data collected from partners throughout an entire supply chain. Such data-based approaches which build on a comprehensive understanding of sustainable development are rare. Only Hassini et al. [16] provide a comparable framework but no specific set of indicators [12].

The information obtained from the indicators can be utilized in business processes such as supplier evaluation, monitoring and selection, procurement, sustainable product development or sustainability reporting. Because this utilization cannot be generalized, we refer to the wide range of process and topic specific approaches, for which the indicator information can provide valuable input (e.g., [50,69-71]). The utilization of the sustainability information into approaches for supplier selection, such as those provided in a recent review by Wetzstein et al. [72], serves as an example. 
Optimally, the suggested indicators are implemented into a software-based sustainability data exchange hub, which would allow for a centrally organized exchange of standardized sustainability information. The implementation of the indicators into such a hub would be beneficial for companies in the sector for various reasons. First, the analysis considered the existing requirements and data exchange practices in the automotive and electronics industries. Therefore, the data required to calculate the indicators are something that companies already have or already exchange along the supply chain. Second, the types of indicators, i.e., qualitative and quantitative, allow for general and/or detailed information exchange between supply chain members. This is particularly relevant when considering the important number of SMEs in supply chains and the fact that companies from different countries and with different regulations take part in the supply chain [73]. The qualitative indicators would enable a light form of data exchange to be carried out by any supply chain members. This may foster the sustainability data exchange already necessary due to legal pressures in the two industries [6].

Although the suggested set of indicators is based on the current scientific literature and the input of industrial experts, it is subject to change and has to evolve over time. Such factors as new regulatory requirements, or the need to adjust to specific cultural contexts, obviously call for indicator adaptation. Furthermore, general barriers in SSCM such as traceability, lack of trust, influence or data confidentiality have to be overcome in order to ensure successful practical implementation [74].

Further research is needed in order to validate and test the indicators empirically by conducting case studies in the supply chains of the automotive or electronics industries. Research is also needed on how the set of indicators might be adapted in order to facilitate their application in other industries or at other levels of aggregation, such as at the regional or country level.

Supplementary Materials: The following are available online at www.mdpi.com/2071-1050/8/11/1185/s1, Table S1: Full list of 69 supply chain sustainability indicators. Rank refers to the rank the sustainability aspect received n Fritz et al. [18]; * For each environmental or social commitment indicator in addition to the answer to the yes/no questions a text description is required. This is not indicated in the table in order to improve readability. Italic $=$ additional indicators, Table S2: Overview of identified standards and templates for supply chain sustainability data exchange $(n=24)$.

Acknowledgments: The authors gratefully acknowledge the research funding provided by the European Commission. The project No. 283130 called Sustainability Data Exchange Hub-SustainHub—was funded under the 7th Framework Programme.

Author Contributions: Josef-Peter Schöggl, Morgane M. C. Fritz and Rupert J. Baumgartner conceived and designed the research process; Josef-Peter Schöggl and Morgane M. C. Fritz conducted the literature review, and the interviews; Josef-Peter Schöggl, Morgane M. C. Fritz and Rupert J. Baumgartner conducted the focus groups and analyzed the data; and Josef-Peter Schöggl, Morgane M.C. Fritz and Rupert J. Baumgartner wrote the paper.

Conflicts of Interest: The authors declare no conflict of interest.

\section{References}

1. Pagell, M.; Shevchenko, A. Why research in sustainable supply chain management should have no future. J. Supply Chain Manag. 2014, 50, 44-55. [CrossRef]

2. Gold, S.; Seuring, S.; Beske, P. Sustainable supply chain management and inter-organizational resources: A literature review. Corp. Soc. Responsib. Environ. Manag. 2010, 245, 230-245. [CrossRef]

3. Diabat, A.; Khodaverdi, R.; Olfat, L. An exploration of green supply chain practices and performances in an automotive industry. Int. J. Adv. Manuf. Technol. 2013, 68, 949-961. [CrossRef]

4. Wittstruck, D.; Teuteberg, F. Understanding the success factors of sustainable supply chain management: Empirical evidence from the electrics and electronics industry. Corp. Soc. Responsib. Environ. Manag. 2012, 158, 141-158. [CrossRef]

5. Electronic Industry Citizenship Coalition (EICC). EICC Offline Questionnaire-Corporate Level; EICC: Alexandria, VA, USA, 2014.

6. Diabat, A.; Govindan, K. An analysis of the drivers affecting the implementation of green supply chain management. Resour. Conserv. Recycl. 2011, 55, 659-667. [CrossRef] 
7. European Parliament; Council of the European Union. Directive 2000/53/EC of the European Parliament and of the Council of 18 September 2000 on End-of Life Vehicles; European Commission: Brussels, Belgium, 2000; Volume 269, p. 34.

8. European Commission. Directive 2002/95/EC on the Restriction of the Use of Certain Hazardous Substances in Electrical and Electronic Equipment; European Commission: Brussels, Belgium, 2002.

9. European Commission. Regulation (EU) No 333/2014 of the European Parliament and of the Council of 11 March 2014 Amending Regulation (EC) No 443/2009 to Define the Modalities for Reaching the 2020 Target to Reduce $\mathrm{CO}_{2}$ Emissions from New Passenger Cars; European Commission: Brussels, Belgium, 2014.

10. Jameson, N.J.; Song, X.; Pecht, M. Conflict minerals in electronic systems: An overview and critique of legal initiatives. Sci. Eng. Ethics 2015, 22, 1375-1389. [CrossRef] [PubMed]

11. Koplin, J.; Seuring, S.; Mesterharm, M. Incorporating sustainability into supply management in the automotive industry-The case of the Volkswagen AG. J. Clean. Prod. 2007, 15, 1053-1062. [CrossRef]

12. Schöggl, J.-P.; Fritz, M.M.C.; Baumgartner, R.J. Toward supply chain-wide sustainability assessment: A conceptual framework and an aggregation method to assess supply chain performance. J. Clean. Prod. 2016, 131, 822-835. [CrossRef]

13. Bai, C.; Sarkis, J. Integrating sustainability into supplier selection with grey system and rough set methodologies. Int. J. Prod. Econ. 2010, 124, 252-264. [CrossRef]

14. Büyüközkan, G.; Çifçi, G. A novel hybrid MCDM approach based on fuzzy DEMATEL, fuzzy ANP and fuzzy TOPSIS to evaluate green suppliers. Expert Syst. Appl. 2012, 39, 3000-3011. [CrossRef]

15. Chung, C.-C.; Chao, L.-C.; Lou, S.-J. The Establishment of a green supplier selection and guidance mechanism with the ANP and IPA. Sustainability 2016, 8, 259. [CrossRef]

16. Hassini, E.; Surti, C.; Searcy, C. A literature review and a case study of sustainable supply chains with a focus on metrics. Int. J. Prod. Econ. 2012, 140, 69-82. [CrossRef]

17. Ahi, P.; Searcy, C. An analysis of metrics used to measure performance in green and sustainable supply chains. J. Clean. Prod. 2014, 86, 360-377. [CrossRef]

18. Fritz, M.; Schöggl, J.-P.; Baumgartner, R.J. Selected sustainability aspects for supply chain data exchange: Towards a supply chain-wide sustainability assessment. J. Clean. Prod. 2017, 141, 587-607. [CrossRef]

19. Sukitsch, M.; Engert, S.; Baumgartner, R.J. The implementation of corporate sustainability in the European automotive industry: An analysis of sustainability reports. Sustainability 2015, 7, 11504-11531. [CrossRef]

20. Björklund, M.; Martinsen, U.; Abrahamsson, M.; Björklund, M. Performance measurements in the greening of supply chains. Supply Chain Manag. Int. J. 2012, 17, 29-39. [CrossRef]

21. Brandenburg, M.; Govindan, K.; Sarkis, J.; Seuring, S. Quantitative models for sustainable supply chain management: Developments and directions. Eur. J. Oper. Res. 2014, 233, 299-312. [CrossRef]

22. Clift, R. Metrics for supply chain sustainability. Clean Technol. Environ. Policy 2003, 5, 240-247. [CrossRef]

23. Courville, S. Use of indicators to compare supply chains in the coffee industry. Greener Manag. Int. 2003, 93-105. [CrossRef]

24. Veleva, V.; Ellenbecker, M. Indicators of sustainable production: Framework and methodology. J. Clean. Prod. 2001, 9, 519-549. [CrossRef]

25. World Commission on Environment and Development. Our Common Future; Oxford University Press: New York, NY, USA, 1987.

26. Elkington, J. Cannibals with Forks: The Triple Bottom Line of 21st Century Business; New Society Publishers: Gabriola Island, BC, Canada, 1998.

27. Mentzer, J.J.T.; Dewitt, W.; Keebler, J.J.S.; Min, S.; Nix, N.W.; Smith, C.D.; Zacharia, Z.G. Defining supply chain management. J. Bus. Logist. 2001, 22, 1-25. [CrossRef]

28. Ahi, P.; Searcy, C. A comparative literature analysis of definitions for green and sustainable supply chain management. J. Clean. Prod. 2013, 52, 329-341. [CrossRef]

29. Fink, A. Conducting Research Literature Reviews: From the Internet to Paper, 2nd ed.; SAGE Publications, Inc.: Thousand Oaks, CA, USA, 2005.

30. Mayring, P.; Gläser-Zikuda, M. Die Praxis der Qualitativen Inhaltsanalyse, 2nd ed.; Beltz Verlagsgruppe: Weinheim, Germany, 2008.

31. Glaser, B.G.; Strauss, A.L. The Discovery of Grounded Theory: Strategies for Qualitative Research; Transaction Publishers: Piscataway, NJ, USA, 1967; Volume 1. 
32. Henseling, C.; Hahn, T.; Nolting, K. Die Fokusgruppen-Methode als Instrument in der Umweltund Nachhaltigkeitsforschung; Institut für Zukunftsstudien und Technologiebewertung (IZT): Berlin, Germany, 2006.

33. Shokravi, S.; Kurnia, S. A step towards developing a sustainability performance measure within industrial networks. Sustainability 2014, 6, 2201-2222. [CrossRef]

34. Singh, R.K.; Murty, H.R.; Gupta, S.K.; Dikshit, A.K. An overview of sustainability assessment methodologies. Ecol. Indic. 2012, 15, 281-299. [CrossRef]

35. Böhringer, C.; Jochem, P.E.P. Measuring the immeasurable-A survey of sustainability indices. Ecol. Econ. 2007, 63, 1-8. [CrossRef]

36. Carter, C.R.; Rogers, D.S. A framework of sustainable supply chain management: Moving toward new theory. Int. J. Phys. Distrib. Logist. Manag. 2008, 38, 360-387. [CrossRef]

37. Sloan, T.W. Measuring the sustainability of global supply chains: Current practices and future directions. J. Glob. Bus. Manag. 2010, 6, 92-107.

38. Shen, L.; Olfat, L.; Govindan, K.; Khodaverdi, R.; Diabat, A. A fuzzy multi criteria approach for evaluating green supplier's performance in green supply chain with linguistic preferences. Resour. Conserv. Recycl. 2012, 74, 170-179. [CrossRef]

39. Shaw, K.; Shankar, R.; Yadav, S.S.; Thakur, L.S. Supplier selection using fuzzy AHP and fuzzy multi-objective linear programming for developing low carbon supply chain. Expert Syst. Appl. 2012, 39, 8182-8192. [CrossRef]

40. Kumar, D.T.; Palaniappan, M.; Kannan, D.; Shankar, K.M. Analyzing the CSR issues behind the supplier selection process using ISM approach. Resour. Conserv. Recycl. 2014, 92, 268-278. [CrossRef]

41. Bojarski, A.D.; Laínez, J.M.; Espuña, A.; Puigjaner, L. Incorporating environmental impacts and regulations in a holistic supply chains modeling: An LCA approach. Comput. Chem. Eng. 2009, 33, 1747-1759. [CrossRef]

42. Tseng, M.; Geng, Y. Evaluating the green supply chain management using life cycle assessment approach in uncertainty. WSEAS Trans. Environ. Dev. 2012, 8, 133-157.

43. Gunasekaran, A.; Patel, C.; McGaughey, R.E. A framework for supply chain performance measurement. Int. J. Prod. Econ. 2004, 87, 333-347. [CrossRef]

44. Kannegiesser, M.; Günther, H.-O.; Gylfason, Ó. Sustainable development of global supply chains-Part 2: investigation of the European automotive industry. Flex. Serv. Manuf. J. 2013, 26, 48-68. [CrossRef]

45. Olugu, E.U.; Wong, K.Y.; Shaharoun, A.M. Development of key performance measures for the automobile green supply chain. Resour. Conserv. Recycl. 2011, 55, 567-579. [CrossRef]

46. Genovese, A.; Acquaye, A.A.; Figueroa, A.; Koh, S.C.L. Sustainable supply chain management and the transition towards a circular economy: Evidence and some applications. Omega 2015, 1-14. [CrossRef]

47. Wang, Y.F.; Chen, S.P.; Lee, Y.C.; Tsai, C.T. Developing green management standards for restaurants: An application of green supply chain management. Int. J. Hosp. Manag. 2013, 34, 263-273. [CrossRef]

48. Hanson, J.; Holt, D. Sustainable food procurement in British and Irish zoos. Br. Food J. 2014, 116, $1636-1651$. [CrossRef]

49. Salvado, M.; Azevedo, S.; Matias, J.; Ferreira, L. Proposal of a sustainability index for the automotive industry. Sustainability 2015, 7, 2113-2144. [CrossRef]

50. Chen, X.; Xiu, G. Empirical studies of green supply chain management performance evaluation based on the ANP. J. Theor. Appl. Inf. Technol. 2013, 48, 1757-1762.

51. Global Reporting Initiative. G4 Sustainability Reporting Guidelines. Reporting Principles and Standard Disclosures; Global Reporting Initiative: Amsterdam, The Netherlands, 2014.

52. Conflict-Free Sourcing Initiative. Conflict Minerals Reporting Template; Conflict-Free Sourcing Initiative: Alexandria, VA, USA, 2015.

53. Institution of Chemical Engineers (IChemE). The Sustainability Metrics: Sustainable Development Progress Metrics Recommended for Use in the Process Industries; IChemE: Rugby, UK, 2002.

54. Howarth, G.; Hadfield, M. A sustainable product design model. Mater. Des. 2006, 27, 1128-1133. [CrossRef]

55. Adhitya, A.; Halim, I.; Srinivasan, R. Decision support for green supply chain operations by integrating dynamic simulation and LCA indicators: Diaper case study. Environ. Sci. Technol. 2011, 45, 10178-10185. [CrossRef] [PubMed]

56. Electronic Industry Citizenship Coalition (EICC). EICC Offline Questionnaire_Facility Level; EICC: Alexandria, VA, USA, 2014. 
57. Electric Utility Industry Sustainable Supply Chain Alliance (EUI SSCA). Electric Utility Industry Sustainable Supply Chain Alliance "Policy \& Environmental Management". 2013. Available online: http:/ / euissca.org/ pdf/EnvironmentalQuestiosnForRFP.pdf (accessed on 1 June 2014).

58. Supplier Ethical Data Exchange (SEDEX). Sedex Members Ethical Trade Audit (SMETA) Report. Available online: http:/ / www.sedexglobal.com/ethical-audits/smeta/ (accessed on 13 November 2016).

59. United Nations. Indicators of Sustainable Development: Guidelines and Methodologies; United Nations Publications: New York, NY, USA, 2007.

60. OHSAS Project Group. OHSAS 18001:2007 Occupational Health and Safety Management Systems, Requirements; OHSAS Project Group: London, UK, 2007.

61. Grambow, G.; Mundbrod, N.; Kolb, J.; Reichert, M. Towards collecting sustainability data in supply chains with flexible data collection processes. In Lecture Notes in Business Information Processing; van der Aalst, W.M.P., Mylopoulos, J., Rosemann, M., Shaw, M.J., Szyperski, C., Eds.; Springer: Berlin/Heidelberg, Germany, 2015; Volume 203, pp. 25-47.

62. Beske, P.; Seuring, S. Putting sustainability into supply chain management. Supply Chain Manag. 2014, 19, 322-331. [CrossRef]

63. Mueller, M.; dos Santos, V.G.; Seuring, S. The contribution of environmental and social standards towards ensuring legitimacy in supply chain governance. J. Bus. Ethics 2009, 89, 509-523. [CrossRef]

64. Srivastava, S.K. Green supply-chain management: A state-of-the-art literature review. Int. J. Manag. Rev. 2007, 9, 53-80. [CrossRef]

65. SustainHub Sustainability Data Exchange Hub-Project Overview. Available online: http://sustainhubresearch.eu/index.php/project-overview (accessed on 22 July 2016).

66. Baumgartner, R.J.; Fritz, M.; Resel, K.; Schiffleitner, A.; Schöggl, J.-P. Sustainhub-A software solution for Sustainable supply chain management in the electronics industry. In Proceedings of the Going Green-CARE INNOVATION Conference, Vienna, Austria, 17-20 November 2014.

67. Boyson, S.; Corsi, T.; Verbraeck, A. The e-supply chain portal: A core business model. Transp. Res. E Logist. Transp. Rev. 2003, 39, 175-192. [CrossRef]

68. European Commission. Access to Finance for SMEs. Available online: http://ec.europa.eu/growth/accessto-finance_en (accessed on 25 October 2016).

69. Ertay, T.; Kahveci, A.; Tabanlı, R.M. An integrated multi-criteria group decision-making approach to efficient supplier selection and clustering using fuzzy preference relations. Int. J. Comput. Integr. Manuf. 2011, 24, 1152-1167. [CrossRef]

70. Pradhan, S.K.; Routroy, S. Analyzing the performance of supplier development: A case study. Int. J. Product. Perform. Manag. 2014, 63, 209-233.

71. Sahu, A.K.; Datta, S.; Mahapatra, S.S. Green supply chain performance benchmarking using integrated IVFN-TOPSIS methodology. Int. J. Process Manag. Benchmarking 2013, 3, 511-551. [CrossRef]

72. Wetzstein, A.; Hartmann, E.; Benton, W.C., Jr.; Hohenstein, N.-O.; Benton, W.C. A systematic assessment of supplier selection literature-State-of-the-art and future scope. Int. J. Prod. Econ. 2016, 182, 304-323. [CrossRef]

73. Ayuso, S.; Roca, M.; Colomé, R. SMEs as "transmitters" of CSR requirements in the supply chain. Supply Chain Manag. Int. J. 2013, 18, 497-508. [CrossRef]

74. Mathiyazhagan, K.; Govindan, K.; NoorulHaq, A.; Geng, Y. An ISM approach for the barrier analysis in implementing green supply chain management. J. Clean. Prod. 2013, 47, 283-297. [CrossRef]

(C) 2016 by the authors; licensee MDPI, Basel, Switzerland. This article is an open access article distributed under the terms and conditions of the Creative Commons Attribution (CC-BY) license (http://creativecommons.org/licenses/by/4.0/). 